\title{
Pengaruh Kepemimpinan Dan Kompetensi Terhadap Produktivitas Pegawai PPSU (Studi Kasus Di Penanganan Prasarana Dan Sarana Umum Pada Kelurahan Lebak Bulus Jakarta Selatan)
}

\author{
Rahmi Hermawati. ${ }^{1}$, Rizky Radhika Hidayat. ${ }^{2}$ \\ DosenFakultas Ekonomi Universitas Pamulang \\ Email : dosen02024@unpam.ac.id
}

\begin{abstract}
As for the purpose of this study is to find and obtains evidence empirical and conclusions about influence style leadership and competence of the productivity employees infrastructure and facilities common (PPSU) in urban lebak bulus of south jakarta.

Research methodology used is associative with the quantitative approach. A method of the withdrawal of in the sample have used of these tests are the sampling method of saturated pt pgn promised to supply dating techniques in the entire household sample if all members of a percent of the population used as included in the research sample. Data collection method that we use is to a method of kuosioner and observation to the employees PPSU to officials in urban village lebak bulus of south jakarta. The method of analysis processing the data used was test validity, reabilitas test, test the assumption classical, regression analysis multiple, analysis koefisiensi determination ( $r 2$ ), the hypothesis (test $f$ and $t$ ).

Based on the results of the analysis that has been done obtained that is the or relation a positive and welfare between style leadership and competence to productivity employees together or simultaneous is as much as $r=0,377$, this showed that productivity employees at PPSU urban village lebak bulus south jakarta effected by force leadership and competence to a category strong contributing $37.7 \%$, while or $62.3 \%$ influenced by other factors out variables tested in pengelitian this.The results of the regression equation is linear multiple namely $y=27,117+0,008 X_{1}+0,817 X_{2}$ means if the force of leadership $\left(X_{1}\right)$ up 1 a unit of then will increase 0,008 and competence $\left(X_{2}\right)$ up 1 a unit of then will increase 0,817.Influence between leadership and competence to productivity employees is significant.This can be seen of the value off count 25,972 > f table 3,10
\end{abstract}

\section{Key Words : Leadership, Competence, Productivity}




\section{PENDAHULUAN}

Demi kelancaran laju rodanya aktivitas organisasi, maka setiap organisasi baik itu organisasi pemerintahan maupun swasta selamanya tidak bisa terlepas dari peran sumber daya manusia. Hal terjadi dikarenakan tingkat kemajuan ilmu pengetahuan dan teknologi yang berkembang masih tetap membutuhkan sumber daya manusia dalam menjalankannya. Sumber daya manusia sangat diperlukan terutama dalam menjalankan tugas-tugas yang berkaitan dengan sektor yang berhubungan dengan pelayanan masyarakat sesuai kebutuhan manusia itu sendiri. Salah satunya yang berkaitan langsung adalah sektor pelayanan baik yang bersifat pelayanan barang atau jasa. Pelayanan tersebut merupakan kebutuhan masyarakat yang harus dapat dipenuhi dengan baik, dimana tugas untuk memberikan pelayanan kepada masyarakat pada umumnya merupakan tugas pokok suatu pemerintahan. Dalam suatu lembaga atau organisasi pasti ada seorang pemimpin yang dapat mengatur kegiatan organisasi agar dapat mencapai tujuan secara efektif dan efisien. Pelatihan dan pengalaman seorang atasan atau pemimpin perusahaan memberikan andil besar terhadap keberhasilan perusahaan. Menurut Sagala (2018:24) mengatakan bahwa keampuhan aktivitas-aktivitas ini oleh Fayol dalam manejemen sudah diuji bahwa kepemimpinan yang mengendalikan perusahaan memainkan peranan penting untuk menjadi manajemen yang efektif dan produktif. Hasibuan (2017:170) mengatakan bahwa kepemimpinan adalah cara seseorang mempengaruhi perilaku bawahannya , agar mau bekerja sama dan bekerja secara produktif untuk mencapai tujuan organisasi. Setiap pemimpin memiliki kepemimpinan yang berbeda-beda satu dengan yang lainnya.. Pelaksanaan kepemimpinan cenderung menumbuhkan kepercayaan, loyalitas, partisipasi, dan internal motivasi para bawahannya dengan cara persuasif. Hal ini semua akan diperoses melalui kecakapan, kemampuan, dan perilakunya dengan tujuan untuk mendoring gairah kerja, kepusasan kerja, dan produktivitas kerja pegawai yang tinggi, agar dapat mencapai tujuan organisasi yang maksimal.

Menurut Powel dalam Oren Harari (2016:18) kepemimpian yang efektif meliputi spektrum penuh tanggung jawab dan juga sepanjang waktu. Dalam selurih organisasi yang melibatkan berbagi macam orang yang terlibat dalam tugas-tugas yang banyak (yang dilakukan secara bersamaan ataupun bertahap), sang pemimpin harus menampilakn performa yang tinggi dan memperhatikan kesejahteraan kelompok. Tetapi Seringkali menjumpai adanya pemimpin yang menggunakan kekuasaannya secara mutlak dengan memerintahkan para bawahannya tanpa memperhatikan keadaan yang ada pada bawahannya

Dalam mengatur kegiatan perusahaan seorang pemimpin diharuskan juga untuk memperhatikan kompetensi yang dimiliki oelah bawahannya. Menurut Palan dalam Fuad dan Gofur (2009:18) menyakatakan bahwa kompetensi sebagi deskriptif adalah perilaku. Secara lebih terperinci deskriptif itu merujuk kepada 
karakteristik yang mendasari perilaku yang menggambarkan motif, karakteristik pribadi, konsep diri, nilai-nilai, pengetahuan, atau keahlian. Kompetensi pegawai merupakan hal yang dimiliki pegawai dalam melakukan pekerjaannya. Semakin tinggi kompetensi pegawai maka akan semakin tinggi pengetahuan tentang bagaimana harus bekerja secara efektif dan efisien. Menurut Sutrisno (2016:203) kompetensi adalah suatu kemampuan yang dilandasi oleh keterampilan dan pengetahuan yang didukung oleh sikap kerja serta penerapannya dalam melaksanakan tugas dan pekerjaan di tempat kerja yang mengacu pada persyaratan kerja yang ditetapkan. . Dalam rangka operasional, kompetensi tersebut membuat sumber daya manusia mampu menggali potensi sumber daya-sumber daya lain yang dimiliki perusahaan. Dengan adanya kompetensi ini, sumber daya manusia dilihat sebagai manusia dengan keunikannya yang perlu dikembangkan. Manusia dilihat sebagai aset atau modal yang berharga. Sumber daya manusia yang dihargai akan bekerja dengan sepenuh hati untuk memberikan yang terbaik bagi organisasi dimana dia berkontribusi. Berdasarkan data statistik Kementerian Perencanaan Pembangunan Nasional, jumlah penduduk Indomesia tahun 2018 adalah 265 juta jiwa dengan kategori usia produktif (14-64 tahun) 179.13 juta jiwa. Hal ini menunjukkan perlunya kompetensi yang mempunyai nilai tambah (added Value) bagi SDM agar dapat diterima bekerja di perusahaan.lokal, multinasional maupun di pemerintahan. Dan berdasarkan data
Human Capital Index negara Asean. untuk soal high-skilled employment share, Indonesia berada di peringkat ketiga terbawah, dengan skor 9,9. Nilai Indonesia ini sangat jauh dibandingkan dengan Singapura tempat pertama, dengan skor 56,2; ataupun Brunai Darussalam, dengan skor 40,8. Ironisnya, Indonesia berada di bawah Myanmar dan Vietnam.

Jika kompetensi yang dimiliki SDM kurang memadai maka akan menggangu produktivitas pegawai dan produktivitas organisasi. Menurut Adryanti (2012:204) mengatakan bahwa keberhasilan organisasi pada umumnya dan perusahaan pada khususnya, sangat tergantung pada tingkat produktivitas orang-oarng yang terlibat di dalamnya. Produktivitas hanya akan muncul jika karyawan mengetahui apa yang diharapkan dari kinerjanya, memiliki kompetensi yang memadai untuk memenuhi harapan itu. Jika organisasi menginginkan berhasil mencapai visi, misi dan tujuan yang telah ditetapkan, tindakan terpenting yang perlu dilakukan adalah berupaya dengan meningkatkan produktivitas pegawai. Peran serta pimpinan sangatlah diperlukan agar terjalin hubungan kedekatan saling mendukung antara atasan dan bawahan. Selain itu juga atasan harus memikirkan pelatihan apa yang cocok bagi pegawai untuk meningkatkan kompetensi bawahan sehingga dapat melakukan pekerjaannya seuai dengan yang diharapkan. Organisasi membutuhkan pemimpin-pemimpin yang mampu membimbing bawahannya. Pemimpin yang terampil dalam terampil mengenali keunggulan bawahannya, dan mendayagunakannya

untuk 
kepentingan bersama, pemimpin yang bisa mengidentifikasi kekuarnagn bawahannya, tanpa menjadikannya sebagai penghambat produktivitas.

Berdasarkan hal tersebut diatas penulis ingin meneliti Kelurahan Lebak Bulus, Jakarta Selatan, yang ditemukan adanya fenomena pegawai di lembaga Penanganan Prasarana dan Sarana Umum (PPSU) yang menjadi ujung tombak dalam pelayanan kepada masyarakat dalam menangani dan merawat segala fasilitas yang sudah dibangun pemerintah sehingga menjadi optimal penggunaannya. Sebagai Pejabat Pelaksana Teknis Kegiatan (PPTK) menginformasikan mengenai aturan kerja, informasi lain, memotivasi para pegawai yang bekerja dilapangan dan menujuk seorang pegawai untuk menjadi kepanjangan tangannya dan harus memberikan laporan bagaimana kerja dari pegawai dilapangan sehingga pengawasan dapat berjalan secara maksimal dan tujuan yang sudah ditetapkan dapat tercapai. Dalam pra penelitian diberikan kuesioner kepada 20 orang pegawai untuk menilai keteladanan, kewibawaan, pendelagasian tugas, pengambilan keputusan dan motivasi pimpinan. Dari hasil pengolahan data ditemukan bahwa $38 \%$ responden setuju bahwa pemimpin mempunyai kriteria tersebut di atas, $41 \%$ raguragu dan $21 \%$ tidak setuju, yang artinya pemipin belum sesuai dengan kriteria yang diharapkan.

Dalam setiap pekerjaan tentulah harus ada suatu kompetensi yang dimiliki setiap pegawai, yang mampu dan mau menggunakan serta dapat mengoperasional- kan alat-alat yang sudah disediakan oleh suatu organisasi. Kompetensi yang dimiliki juga berbeda pada setiap orang. Pegawai belum dapat mengoperasikan alat-alat yang ada dan pastinya akan mengandalkan orang yang sudah menguasai alat tersebut sehingga menimbulkan ketergantungan. Pada penelitian ini penulis melakukan observasi bagaimana pegawai dapat mengoptimalisasikan peralatan canggih dalam enjalankan tugasnya sebagi pegawai kebersihan. Ditemukan bahwa pegawai belum dapat menggunakan seluruh peralatan yang disediakan, pegawai masih menggunakan alat tradisional untuk memotong rumput, pengangkatan sampah pada gorong-gorong air memakan waktu lumayan lama karena mengandalkan pegawai lain tanpa menggunakan peralatan modern yang telah disediakan.Dan beberapa pegawai belum menguasai bagaimana instalasi listrik lampu jalan. Kurangnya pengetahuan dan kemampuan mereka ini menyebabkan mengandalkan pegawai lain dan mengerjakan apa yang bisa dikerjakan saja.

Permasalahan yang terjadi di atas tentulah dapat mengganggu produktivitas kerja pegawai maupun organisasi (PPSU). Produktivitas pegawai dapat dinilai dari kemampuan, meningkatkan hasil yang dicapai, semangat kerja, pengembangan diri, mutu dan efisiensi. Untuk meningkatkan produktivitas yang diinginkan, pegawai harus dapat bekerja dengan penuh semangat kerja. Setiap hari kemampuan pekerja akan terus bertambah seiring pengalaman dilapangan yang didapat, dan semangat kerja pun dapat dilihat dari jumlah cuti yang dipergunakan oleh 
pegawai. Dari data sekunder maka data kinerja pegawai berdasarkan absensi sbb:

Tabel 1.1

Rekap Cuti Tahunan Pegawai PPSU

\begin{tabular}{|c|c|c|c|c|}
\hline No. & $\begin{array}{l}\text { Kode } \\
\text { Warna }\end{array}$ & \begin{tabular}{|c|} 
Jumlah \\
Pegawai
\end{tabular} & Prosentase & Keterangan \\
\hline 1 & Merah & 23 & $26 \%$ & $\begin{array}{c}\text { Jumlah cuti tahunan } 9 \mathrm{~s} / \mathrm{d} \leq 12 \\
\text { hari }\end{array}$ \\
\hline 2 & Kuning & 49 & $55 \%$ & $\begin{array}{c}\text { Jumlah cuti tahunan } 6 \mathrm{~s} / \mathrm{d} \leq 8 \\
\text { hari }\end{array}$ \\
\hline 3 & Hijau & 17 & $19 \%$ & $\begin{array}{c}\text { Jumlah cuti tahunan } 0 \mathrm{~s} / \mathrm{d} \leq 5 \\
\text { hari }\end{array}$ \\
\hline \multicolumn{2}{|c|}{ Jumlah } & 89 & $100 \%$ & \\
\hline
\end{tabular}

Tabel diatas produktivitas yang dinilai dari semangat kerja pegawai dinilai berdasarkan penggunaan cuti pegawai. Prosentase pegawai yang berada di kode merah adalah sebesar $26 \%$ hal ini lebih tinggi dari pada kode warna hijau yang memiliki prosentase $19 \%$ dalam pengambilan cuti pegawai, dan mayoritas berada di kode warna kuning sebesar 55\%, pegawai masih memanfaatkan waktu cuti dibandingkan dengan bekerja secara penuh.

$$
\text { Berdasarkan fenomena- }
$$

fenomena yang telah diobservasi, maka penulis tertarik untuk menganalisa seberapa besar pengaruh kepemimpinan dan kompetensi untuk meningkatkan produktivitas pegawai, sehingga penulis mengambil judul "Pengaruh Kepemimpinan dan Kompetensi Terhadap Produktivitas Pegawai Penanganan Prasarana dan Sarana Umum pada Kelurahan Lebak Bulus Jakarta Selatan".

\section{TINJAUAN PUSTAKA \\ Pengertian Kepemimpinan}

Salah satu tantangan terberat yang sering harus dihadapi oleh seorang pimpinan atau atasan suatu perusahaan adalah bagaimana ia dapat menggerakkan para pegawainya agar senantiasa mau dan bersedia mengerahkan kemampuan yang terbaiknya untuk kepentingan organisasi atau perusahaan. Salah satu usaha guna mengarahkan karyawan agar berperilaku sesuai dengan harapan adalah dengan memberikan contoh terlebih dahulu dari pimpinannya. Menurut Hasibuan (2017:170) kepemimpinan adalah cara seseorang pemimpin mempengaruhi perilaku ba-wahannya , agar mau bekerja sama dan bekerja secara produktif untuk mencapai tujuan organisasi. Sedangkan menurut Sutrisno (2016:218) bahwa kepemimpinan adalah sebagai proses mengarahkan dan mempengaruhi aktivitas yang berkaitan dengan tugas dari para anggota kelompok. Sagala (2018:4140 berpendapat bahwa seorang pemimin berpikir bagaimana bekerja dengan penuh antusiasme, dan mengatasi masalah-masalah seperti perbaikan metode-metode produksi, konsep fundamental untuk metode manufaktur modern, menstandar- disasikan produksi, laporan harga, mem- perbaiki manajemen perusahaan atau organisasi, landasan hukum yang diperlukan, teknologi yang digunakan dan permasalahan lain yang dihadapi. Pemimpin yang berhasl bersama timnya akan yang hebat akan dapat mengatasi masalah dengan baik dan dengan biaya yang kebih efisien. Indikator-indikator yang dgunakan dalam penelitian ini adalah berdasarkan referensi Hasibuan (2009:199), sebagai berikut :

a. Keteladan.

Sebagai instruktur yang baik terhadap bawahannya dengan menjadi pimpinan bijaksana yang memungkinkan setiap bawahan semakin pintar dan profesional dalam melaksanakan tugas. 
b. Kewibawaaan

Pemimpin dapat membantu atau menolong bawahan mengatasi masalah yang dihadapinya dalam pelaksanaan tugas yang dibebankan kepada bawahan tersebut.

c. Pendelegasian tugas

Pemimpin yang bijaksana harus mendelegasikan sebagian tugas dan wewenang kepada bawahannya. Pendelegasian ini diperlukan untuk meminimalisir hambatan.

d. Pengambilan keputusan

Keberhasilan seorang pemimpin sangat ditentukan oleh keterampilan mengambil keputusan di saat kritis sekalipun.

e. Motivasi

Pemimpin memberi pengaruh membangkitkan, mengarahkan dan memelihara perilaku yang berhubungan dengan lingkungan kerja.

Menurut Fiedler dalam Sutrisno (2016:224), tidak ada seseorang yang dapat menjadi pemimpin yang berhasil dengan menerapkan kepemimpinan untuk segala situasi. Untuk itu pemimpin yang berhasil harus mampu menerapkan kepemimpinan yang berbeda-beda sesuai dengan situasi yang berbedabeda pula.

Teori Fiedler dalam Sutrisno (2016:224), mengkhususkan diri pada perilaku pemimpin dalam memimpin yaitu berorientasi kepada tugas atau berorientasi pada bawahan. Ada tiga sifat situasi yang dapat memengaruhui efektivitas kepemimpinan, yaitu:

a. Hubungan antara pemimpin dengan bawahan.

b. Derajat susunan tugas. c. Kedudukan kekuasaan seorang pimpinan. Fiedler (dalam Sutrisno, 2016)

\section{Pengertian Kompetensi}

Kompetensi merujuk kepada karakteristik yang mendasari perilaku yang menggambarkan motif, karakteristik pribadi (ciri khas), konsep diri, nilai-nilai, pengetahuan atau keahlian yang dibawa seseorang yang berkinerja unggul (superior performer) di tempat kerja.

Menurut Organisasi Industri Psikologi Amerika Mitrani, Palziel, and Pitt dalam Sutrisno (2016:202), gerakan tentang kompetensi telah dimulai pada 1960 dan awal 1970. Menurut gerakan tersebut banyak hasil studi yang menunjukkan bahwa hasil tes sikap dan pengetahuan, prestasi belajar di sekolah dan diploma tidak dapat memprediksi produktivitas atau keberhasilan dalam kehidupan. Temuan tersebut telah mendorong dilakukan penelitian terhadap variabel kompetensi yang diduga memprediksi produktivitas individu. Oleh sebab itu, beberapa prinsip yang perlu diperhatikan adalah:

a. Membandingkan individu yang secara jelas berhasil di dalam pekerjaannya dengan individu yang tidak berhasil. Melalui cara ini perlu diidentiflkasikan karakteristik yang berkaitan dengan keberhasilan tersebut.

b. Mengidentiflkasikan pola pikir dan perilaku individu yang berhasil. Pengukuran kompetensi harus me- nyangkut reaksi individu terhadap situasi yang terbuka ketimbang menggantungkan kepada pengukuran responden seperti tes 
pilihan ganda yang meminta individu memilih alternatif jawaban.

Secara harfiah, kompetensi berasal dari kata competence yang artinya kecakapan, kemampuan, dan wewenang Scale dalam Sutrisno (2016:202). Adapun secara ethnologi, kompetensi diartikan sebagai dimensi perilaku keahlian atau keunggulan seorang pemimpin atau staf mempilnyai keterampilan, pengetahuan, dan perilaku yang baik., Boulter, Dalziel, dan Hill dalam Sutrisno (2016:203), mengernukakan kompetensi adalah suatu karakteristik dasar dari seseorang yang memungkinkannya memberikan produktivitas unggul dalam pekerjaan, peran, atau situasi tertentu. Keterampilan adalah hal-hal yang orang bisa lakukan dengan baik. Pengetahuan adalah apa yang diketahui seseorang tentang suatu topik. Peran sosial adalah citra yang ditunjukkan oleh seseorang di muka publik. Peran sosial mewakili apa yang orang itu anggap penting. Peran sosial mencerminkan nilai-nilai orang itu. Menurut Peraturan Pemerintah No. 101 Tahun 2000, kompetensi adalah kemampuan dan karakteristik yang dimiliki oleh seorang pegawai negeri sipil berupa pengetahuan, sikap perilaku yang diperlukan dalam tugas dan jabatannya (Pasal 3). Mulyasa dalam Sutrisno (2016:203), mengemukakan kompetensi merupakan perpaduan dari pengetahuan, keterampilan, nilai, dan sikap yang direfleksikan dalam kebiasaan berpikjr dan bertindak.

Adapun Mc Ashan dalam Sutrisno (2016:203), mengemukakan, kompetensi diartikan sebagai pengetahuan, keterampilan, dan kernampuan yang dikuasai oleh seseorang yang telah menjadi bagian dari dirinya, Schingga ia dapat melakukan perilaku-perilaku kognitif, afektif, dan psikomotorik dengan sebaik-baiknya.

Apabila kompetensi diartikan sama dengan kemampuan, maka dapat diartikan pengetahuan memahami tujuan bekerja, pengetahuan dalam melaksanakan kiat-kiat jitu dalam menyelesaikan pekerjaan yang tepat dan baik, serta memahami betapa pentingnya disiplin dalam organisasi agar semua aturan dapat berjalan dengan baik. Indikator kompetensi menurut Spencer and Spencer dalam Sutrisno (2016:206), terdapat lima aspek yaitu:

a. Motives, adalah sesuatu di mana seseorang secara konsisten berpikir sehingga ia melakukah tindakan. Misalnya, orang memiliki motivasi berprestasi secara konsisten mengembangkan tujuan-tujuan yang memberi tantangan pada dirinya dan bertanggung jawab penuh untuk menrcapai tujuan tersebut serta mengharapkan feedback untuk memperbaiki dirinya.

b. Traits, adalah watak yang membuat orang untuk berperilaku atau bagaimana seseorang merespons sesuatu dengan cara tertentu. Misalnya, percaya diri, kontrol diri, stres, atau ketabahan.

c. Self concept, adalah sikap dan nilai-nilai yang dimiliki seseorang. Sikap dan nilai diukur melalui tes kepada responden untuk mangetahui bagaimana nilai yang dimiliki seseorang, apa yang menarik bagi seseorang melakukan sesuatu. Misalnya, seseorang yang dinilai menjadi 
pimpinan seyogianya memiliki perilaku kepemimpinan sehingga perlu adanya tes tentang leadership ability.

d. Knowledge, adalah informasi yang dimiliki seseorang untuk bidang tertentu. Pengetahuan merupakan kompetensi yang kompleks. Skor atas tes pengetahuan sering gagal untuk memprediksi produktivitas SDM karena skor tersebut tidak berhasil mengukur pengetahuan dan keahlian saperti apa seharusnya dilakukan dalam pekerjaan. Tes pengetahuan mengukur kemampuan peserta tes untuk memilih jawaban yang paling benar, tetapi tidak bisa melihat apakah seseorang dapat melakukan pekerjaan berdasarkan pengetahuan yang dimiliki.

e. Skills, adalah kemampuan untuk melaksanakan suatu tugas tertentu baik secara fisik maupun mental. Misalnya, seorang programmer komputer membuat suatu program yang berkaitan dengan SIM SDM.

Komponen kompetensi yang motif, karakter pribadi, dan konsep diri dapat dapat meramalkan suafu perilaku tertentu yang pada akhirnya akan muncul sebagai prestasi kerja. Kompetensi juga selalu melibatkan intensi (kesengajaan) yang mendorong sejumlah motif atau karakter pribadi untuk melakukan suatu aksi menuju terbentuknya suatu hasil. Prestasi dalam bekerja yang membentuk suatu hasil maka akan akan tercapai produktivitas pegawai yang tinggi.

Menurut Wijono (2000:66) pada model Ohio State University, dikemukakan dua gaya kepemimpinan yang cukup menarik untuk digunakan sebagai salah satu informasi penting ketika memimpin sebuah organisasi, yaitu: (1) gaya penuh dengan perhatian mengandung arti bahwa pemimpin memberikan apresiasi yang setinggi-tingginya diantaranya memberi pujian ataupun penghargaan terhadap para bawahannya yang berhasil dalam meningkatkan produktivitas ataupun kinerjanya. Selain itu, pemimpin memberi dukungan dan simpati terhadap para bawahan yang menghadapi masalah; dan (2) gaya memprakarsai sebuah struktur yang mengandung arti bahwa pemimpin memberi tugas kepada bawahannya sesuia dengan potensi dan kompetensi yang dimiliki mereka. Pemimpin dalam memberikan tugas kepada bawahannya senantiasa harus menggunakan strategi secara sistematis sesuai dengan prosedur yang berstandar dalam mencapai produktivitas dan meningkatkan kinerja karyawannya.

\section{Pengertian Produktivitas}

Produktivitas secara umum diartikan sebagai hubungan antara keluaran (barang-barang atau jasa) dengan memasukan (tenaga kerja, bahan, uang). Produktivitas adalah ukuran efisiensi produktif. Suatu perbandingan antara hasil keluaran dan masukan. Masukan sering dibatasi dengan tenaga kerja, sedangkan keluaran diukur dalam kesatuan fisik, bentuk, dan nilai.

Menurut Sutrisno (2016:102) Produktivitas kerja adalah rasio dari hasil kerja dengan waktu yang dibutuhkan untuk menghasilkan produk dari seorang tenaga kerja.

Menurut Sinungan (2009:17)

Produktivitas adalah suatu pendekatan interdisipliner untuk 
menentukan tujuan yang efektif, pembuatan rencana aplikasi, penggunaan cara yang produktif untuk menggunakan sumber-sumber secara efisien dan tetap menjaga kualitas yang tinggi.

Produktivitas mempunyai pengertian lebih luas dari ilmu pengetahuan, teknologi dan teknik manajemen yaitu sebagai suatu philosopi dan sikap mental yang timbul dari motivasi yang kuat dari masyarakat, yang secara terusmenerus berusaha meningkatkan kualitas kehidupan.

Jadi defmisi produktivitas bukan hanya satu masalah teknis maupun manajerial tetapi merupakan satu masalah yang kompleks, merupakan masalah yang ber- kenaan dengan badan-badan pemerintahan, serikat buruh dan lembaga-lembaga sosial lainnya, yang semakin berbeda tujuannya akan semakin berbeda pula definisi produktivitasnya.

Setiap perusahaan selalu berkeinginan agar tenaga kerja yang dimiliki mampu meningkatkan produktivitas yang tinggi. Produktivitas tenaga kerja dipengaruhi oleh beberapa faktor baik yang berhubungan dengan tenaga kerja itu sendiri maupun faktor lain, seperti tingkat pendidikan, keterampilan, disiplin, sikap dan etika kerja, motivasi, gizi dan kesehatan, tingkat penghasilan, jaminan sosial, lingkungan kerja, iklim kerja, teknologi, sarana produksi, manajemen, dan prestasi menurut Ravianto dalam Sutrisno (2016:102).

Menurut Simanjuntak dalam Sutrisno (2016:103), ada beberapa faktor yang dapat memengaruhi produktivitas kerja karyawan, yaitu: a. Pelatihan.

Latihan kerja dimaksudkan untuk me-lengkapi karyawan dengan keterampilan dan cara-cara yang tepat untuk menggunakan peralatan kerja. Untuk itu, latihan kerja diperlukan bukan saja sebagai pelengkap akan tetapi sekaligus untuk memberikan dasar-dasar penge- tahuan. Karena dengan latihan berarti para karyawan belajar untuk mengerjakan sesuatu dengan benar-benar dan tepat, serta dapat memperkecil atau meninggalkan kesalahan-kesalahan yang pernah dilakukan. Stoner (1991), mengemukakan bahwa peningkatan produktivitas bukan pada pemutakhiran peralatan, akan tetapi pada pengembangan karyawan yang paling utama. Dari hasil penelitian beliau menyebutkan $75 \%$ peningkatan produktivitas justru dihasilkan oleh perbaikan pelatihan dan pengetahuan kerja, kesehatan dan alokasi tugas.

b. Mental dan kemampuan fisik karyawan.

Keadaan mental dan lisik karyawan merupakan hal yang sangat penting untuk menjadi perhatian bagi organisasi, sebab keadaan fisik dan mental karyawan mempunyai hubungan yang sangat erat dengan produktivitas kerja karyawan.

c. Hubungan antara atasan dan bawahan.

Hubungan atasan dan bawahan akan memengaruhi kegiatan yang dilakukan sehari-hari. Bagaimana pandangan atasan terhadap bawahan, sejauh mana bawahan diikutsertakan dalam penentuan 
tujuan. Sikap yang saling jalinmenjalin telah mampu meningkatkan produktivitas karyawan dalam bekerja. Dengan demikian, jika karyawan diperlakukan secara baik, maka karyawan tersebut akan berpartisipasi dengan baik pula dalam proses produksi, sehingga akan berpengaruh pada tingkat produktivitas kerja.

Adapun Tiffm dan Cormick dalam Sutrisno (2016:103), mengatakan bahwa faktor-faktor yang memengaruhi produktivitas kerja dapat disimpulkan menjadi dua golongan, yaitu:

a. Faktor yang ada pada diri individu, yaitu umur, temperamen, keadaan fisik individu, kelehan, dan motivasi.

b. Faktor yang ada di luar individu, yaitu kondisi fisik seperti suara, penerangan, waktu istirahat, lama kerja, upah, bentuk organisasi, lingkungan sosial, dan keluarga.

Dengan demikian, jika karyawan diperlakukan secara baik oleh atasan atau adanya hubungan antar karyawan /pegawai/ pekerja yang baik, maka karyawan/pegawai/ pekerja tersebut akan berpartisipasi dengan baik pula dalam proses produksi, sehingga akan berpengaruh pada tingkat produktivitas kerja. Produktivitas merupakan hal yang sangat penting bagi para karyawan yang ada di perusahaan. Dengan adanya produktivitas kerja diharapkan pekcrjaan akan terlaksana secara eflsien dan efektif, sehingga ini semua akhirnya sangat diperlukan dalam pencapaian tujuan yang sudah ditetapkan. Untuk mengukur produktivitas kerja, diperlukan suatu indikator, sebagai berikut: a. Kemampuan.

Mempunyai kemampuan untuk melaksanakan tugas. Kemampuan se- orang karyawan sangat bergantung pada keterampilan yang dimiliki serta profesionalisme mereka dalam bekerja. Ini memberikan daya untuk menye- lesaikan tugas-tugas yang diembannya kepada mereka.

b. Meningkatkan hasil yang dicapai.

Berusaha untuk meningkatkan hasil yang dicapai. Hasil merupakan salah satu yang dapat dirasakan baik oleh yang mengerjakan maupun yang menikmati hasil pekerjaan tersebut. Jadi, upaya untuk memanfaatkan produktivitas kerja bagi masing-masing yang terlibat dalam suatu pekerjaan.

c. Semangat kerja.

Ini merupakan usaha untuk lebih baik dari hari kemarin. Indikator ini dapat dilihat dari etos kerja dan hasil yang dicapai dalam satu hari kemudian dibandingkan dengan hari sebelumnya.

d. Pengembangan diri.

Senantiasa mengembangkan diri untuk meningkatkan kemampuan kerja. Pengembangan diri dapat dilakukan dengan melihat tantangan dan harapan dengan apa yang akan dihadapi. Sebab semakin kuat tantangannya, pengembangan diri mutlak dilakukan. Begitu juga harapan untuk menjadi lebih baik pada gilirannya akan sangat berdampak pada keinginan karyawan untuk meningkatkan kemampuan.

e. Mutu.

Selalu berusaha untuk meningkatkan mutu lebih baik dari yang telah lalu. Mutu merupakan 
basil pekerjaan yang dapat menunjukkan kualitas kerja seorang pegawai. Jadi, meningkatkan mutu bertujuan untuk memberikan hasil yang terbaik yang pada gilirannya akan sangat berguna bagi perusahaan dan dirinya sendiri.

f. Efisiensi.

Perbandingan antara hasil yang dicapai dengan keseluruhan sumber daya yang digunakan. Masukan dan keluaran mempakan aspek produktivitas yang memberikan pengaruh yang cukup signifikan bagi

Produktivitas menurut

Yunarsih dan Suswanto dalam Mahanggoro (2018:16) adalah sebagai hasil konkrit (produk) yang dihasilkan oelh individu atau kelompok, selama waktutertentu dalam suatu proses kerja. Produktivitas dalam arti teknis mengacu pada derajat keefektifan dan efisiensi dalam pemanfaatan berbagi sumber daya, Produktivitas dalam pengertian perilaku merupakan suatu sikap mental yang senantiasa berusaha untuk berkembang. Oleh karena itu tentu diperlukan kompetensi dan arahan dari pimpinan agar produktivitas pegawai meningkat sehingga meningkatkan juga produktivitas organisasi secara keselurihan.

Mahanggor

mengatakan bahwa faktor-faktor yang berpengaruh terhadap produktivitas kerja dapat digolongkan menjadi dua golongan yaitu faktor internal dan faktor eksternal. Faktor internal meliputi komitmen kuat terhadap visi dan misi organisasi, struktur dan desain pekerjaan, motivasi, disiplin serta etos kerja yang mendukung ketercapaian target, dukungan sumber daya yang bisa digunakan untuk menunjang kelancaraan pelaksanaan tugas, kebijakan perusahaan yang bisa merangsang (trigger) kreativitas dan inovasi, perlakuan menyenangkan yang bisa diberikan pimpinan atau rekan kerja, praktik manajemen yang diterapkan pimpinan, lingkungan kerja ergonomis, kesesuaian antara tugas yang diemban dengan latar belakang pendidikan, pengalaman, minat, keahlian, maupun keterampilan yang di-kuasai, komuniaksi inter dan antar individu dalam membangun kerja.

\section{METODE PENELITIAN}

Penelitian ini dilaksanakan pada bagian Penanganan Prasana dan Sarana Umum (PPSU) Kantor Kelurahan Lebak Bulus, Jakarta Selatan yang beralamat di Jalan Manunggal Jaya No. 1, Rt.007/04, Lebak Bulus, Cilandak, Jakarta Selatan. Waktu penelitian ini berlangsung pada bulan April s/d September 2018.

Penelitian ini bersifat penelitian kuantitatif asosiatif menggunakan metode survei dengan mengumpulkan data melalui observasi dan penyebaran kuesioner kepada pegawai PPSU kelurahan Lebak Bulus, Jakarta Selatan. departemen produksi, yang hasilnya kemudian diolah melalui program SPSS Versi 23 tahun 2016, untuk mengetahui pengaruh antara variabel kepemimpinan dan kompetensi kompetensi terhadap produktivitas pegawai PPSU. Variabel yang akan diteliti adalah kepemimpinan $\left(\mathrm{X}_{1}\right)$, kompetensi $\left(\mathrm{X}_{2}\right)$, dan produktivitas (Y). 
Populasi dalam penelitian ini adalah keseluruhan subyek penelitian yang dijadikan sasaran. Populasi ini meliputi pegawai yang berjumlah 89 orang.

Sampel dalam penelitian ini adalah sampel jenuh yang artinya semua populasi dalam penelitian digunakan sebagai sampel.

Jadi jumlah sampel adalah sebanyak 89 orang.

Sampel yang akan diambil datanya akan diberikan kuesioner. Kuesioner merupakan penelitian dengan cara mengajukan daftar pernyataan langsung kepada responden. Skala yang digunakan adalah skala Likert (Likert scale) untuk mengukur sikap, pendapat dan persepsi seseorang tentang kejadian atau gejala sosial, menurut Sugiyono (2012:102). Kategori dari penilaian skala Likert 5 (Likert scale 4) adalah sebagai berikut :

SS = Sangat Setujudiberi skor 5

$\mathbf{S} \quad=$ Setuju diberi skor 4

KS = Kurang setuju diberi skor 3

TS = Tidak Setujudiberi skor 2

STS =Sangat Tidak Setuju diberi

skor 1

Dalam penelitian ini akan dijelaskan bahwa hanya ada satu variabel terikat dan tiga variabel bebas:

1. Variabel terikat (Endogen

Variable)

Variabel terikat atau variabel $Y$ dari penelitian ini adalah produktivitas.

2. Variabel bebas (Eksogen Variable) Variabel bebas atau varibel $\mathrm{X}$, terdiri dari tiga variabel, yaitu kepemimpinan $\left(\mathrm{X}_{1}\right)$ dan kompetensi $\left(\mathrm{X}_{2}\right)$

Data yang diperoleh dari penelitian harus dianalisis terlebih dahulu dengan uji validitas dan realibiltas untuk mengetahui apakah butir-butir pernyataan yang ada sudah memenuhi batas alfa. Kemudian dilakukan uji asumsi klasik dengan uji normalitas, homogenitas, autokorelasi, multikolinieritas, dan heterokedastisitas.Uji regresi linier sederhana dan berganda serta koefisien determinasi.

Terakhir dilakukan pengujian hipotesis penelitian untuk melihat seberapa besar pengaruh variabel $\mathrm{X}_{1}$ dan $\mathrm{X}_{2}$ terhadap $\mathrm{Y}$, dengan Uji Parsial t-test dan Uji Simultan F-test.

\section{HASIL DAN PEMBAHASAN}

Dari hasil analisis dengan melihat karakteristik responden Penanganan Prasarana dan Sarana Umum (PPSU) yang berjumlah 89 orang, maka dapat disimpulkan hal-hal sebagai berikut:

1. Berdasarkan data yang dikumpulkan oleh peneliti, telah didapatkan data jumlah karyawan/responden menurut jenis kelaminnya yaitu 85 orang berjenis kelamin perempuan $(95,5 \%)$ dan 4 orang berjenis kelamin laki-laki $(4,5 \%)$.

2. Berdasarkan data yang dikumpulkan oleh peneliti, telah didapatkan data jumlah karyawan/responden menurut usianya yaitu usia 20-30 tahun berjumlah 34 orang ( $38 \%$ ), usia 31-40 tahun berjumlah 14 orang (16\%), dan usia > 40 tahun berjumlah 41 tahun $(46 \%)$.

3. Berdasarkan data yang dikumpulkan oleh peneliti, telah didapatkan data jumlah karyawan/responden menurut pendidikannya yaitu SD berjumlah 1 orang (1\%), SLTP berjumlah 29 (33\%), SLTA berjumlah 56 (63\%), dan S1 
berjumlah 3 orang (3\%).

4. Berdasarkan data yang dikumpulkan oleh peneliti, telah didapatkan data jumlah karyawan/responden menurut lamanya bekerja yaitu lama bekerja 1 tahun berjumlah 6 orang $(7 \%)$, lama bekerja 2 tahun berjumlah 30 orang $(34 \%)$, dan lama bekerja 3 tahun berjumlah 53 orang $(59 \%)$ tahun.

\section{Uji Validitas}

Tabel 4.1 Hasil Uji Validitas Kepemimpinan

\begin{tabular}{|l|c|c|c|c|}
\hline Indikator & Pernyataan & $\begin{array}{c}\text { Nilai r } \\
\text { hitung }\end{array}$ & $\begin{array}{c}\text { Nilai r } \\
\text { tabel }\end{array}$ & Keterangan \\
\hline \multirow{2}{*}{ Keteladanan } & 1 & 0,545 & 0,208 & Valid \\
\cline { 2 - 5 } & 2 & 0,42 & 0,208 & Valid \\
\hline \multirow{2}{*}{ Kewibawaan } & 3 & 0,357 & 0,208 & Valid \\
\cline { 2 - 5 } & 4 & 0,664 & 0,208 & Valid \\
\hline Pendelegasian & 5 & 0,387 & 0,208 & Valid \\
\cline { 2 - 5 } Tugas & 6 & 0,492 & 0,208 & Valid \\
\hline $\begin{array}{l}\text { Pengambilan } \\
\text { Keputusan }\end{array}$ & 7 & 0,664 & 0,208 & Valid \\
\cline { 2 - 5 } & 8 & 0,492 & 0,208 & Valid \\
\hline Motivasi & 9 & 0,357 & 0,208 & Valid \\
\cline { 2 - 5 } & 10 & 0,272 & 0,208 & Valid \\
\hline
\end{tabular}

Tabel 4.2 Hasil Uji Validitas Kompetensi

\begin{tabular}{|l|c|c|c|c|}
\hline \multicolumn{1}{|c|}{ Indikator } & Pernyataan & $\begin{array}{c}\text { Nilai r } \\
\text { hitung }\end{array}$ & $\begin{array}{c}\text { Nilai r } \\
\text { tabel }\end{array}$ & Keterangan \\
\hline \multirow{2}{*}{$\begin{array}{l}\text { Motives (motif } \\
\text { bekerja) }\end{array}$} & 1 & 0,518 & 0,208 & Valid \\
\cline { 2 - 5 } & 2 & 0,257 & 0,208 & Valid \\
\hline $\begin{array}{l}\text { Traits } \\
\text { (karakter }\end{array}$ & 3 & 0,518 & 0,208 & Valid \\
\cline { 2 - 5 } $\begin{array}{l}\text { Self Concept } \\
\text { (konsep diri) }\end{array}$ & 5 & 0,336 & 0,208 & Valid \\
\cline { 2 - 5 } $\begin{array}{l}\text { Knowladge } \\
\text { (pengetahuan) }\end{array}$ & 7 & 0,265 & 0,208 & Valid \\
\cline { 2 - 5 } & 8 & 0,731 & 0,208 & Valid \\
\hline $\begin{array}{l}\text { Skills } \\
\text { (kemampuan) }\end{array}$ & 9 & 0,695 & 0,208 & Valid \\
\cline { 2 - 5 } & 10 & 0,702 & 0,208 & Valid \\
\hline \multirow{2}{*}{$\begin{array}{l}\text { Sumber : Data Primer diolah dengan SPSS 23 } \\
\text { Suld }\end{array}$} & Valid \\
\hline
\end{tabular}

Tabel 4.3Hasil Uji Validitas Kompetensi

\begin{tabular}{|l|c|c|c|c|}
\hline \multicolumn{1}{|c|}{ Indikator } & Pernyataan & $\begin{array}{c}\text { Nilai r } \\
\text { hitung }\end{array}$ & $\begin{array}{c}\text { Nilai r } \\
\text { tabel }\end{array}$ & Keterangan \\
\hline \multirow{2}{*}{ Kemampuan } & 1 & 0,242 & 0,208 & Valid \\
\cline { 2 - 5 } & 2 & 0,289 & 0,208 & Valid \\
\hline Meningkatkan & 3 & 0,403 & 0,208 & Valid \\
\cline { 2 - 5 } hasil yang & 4 & 0,503 & 0,208 & Valid \\
\hline $\begin{array}{l}\text { Semangat } \\
\text { keria }\end{array}$ & 5 & 0,521 & 0,208 & Valid \\
\cline { 2 - 5 } $\begin{array}{l}\text { Pengembangan } \\
\text { diri }\end{array}$ & 6 & 0,441 & 0,208 & Valid \\
\cline { 2 - 5 } & 7 & 0,482 & 0,208 & Valid \\
\cline { 2 - 5 } & 9 & 0,415 & 0,208 & Valid \\
\hline \multirow{3}{*}{ Mutu } & 10 & 0,461 & 0,208 & Valid \\
\cline { 2 - 5 } & 11 & 0,5 & 0,208 & Valid \\
\cline { 2 - 5 } & 12 & 0,218 & 0,208 & Valid \\
\hline \multirow{3}{*}{ Efisiensi } & 13 & 0,37 & 0,208 & Valid \\
\cline { 2 - 5 } & 14 & 0,504 & 0,208 & Valid \\
\cline { 2 - 5 } & 15 & 0,279 & 0,208 & Valid \\
\hline \multirow{2}{*}{ Sumber : Data Primer diolah dengan SPSS 23} &
\end{tabular}

\section{Uji Reliabilitas}

Tabel 4.4 Hasil Uji Reliabilitas Variabel

\begin{tabular}{|l|c|c|c|}
\hline \multicolumn{1}{|c|}{ Variabel } & $\begin{array}{c}\text { Nilai } \\
\text { Alpha }\end{array}$ & Kriteria & Keputusan \\
\hline Kepemimpinan $\left(\mathrm{X}_{1}\right)$ & 0,613 & $>0,60$ & Reliabel \\
\hline Kompetensi $\left(\mathrm{X}_{2}\right)$ & 0,642 & $>0,60$ & Reliabel \\
\hline Produktivitas Pegawai & 0,607 & $>0,60$ & Reliabel \\
\hline
\end{tabular}

Sumber : Data Primer diolah dengan SPSS 23

Berdasarkan hasil uji reliabilitas di atas diketahui semua variabel diperoleh nilai Cronbach Alpha lebih besar dari $r$ tabel dan nilai $r$ adalah positif, maka butir pernyataan dalam variabel dikatakan reliabel.

\section{Uji Asumsi Klasik}

\section{Uji Normalitas}

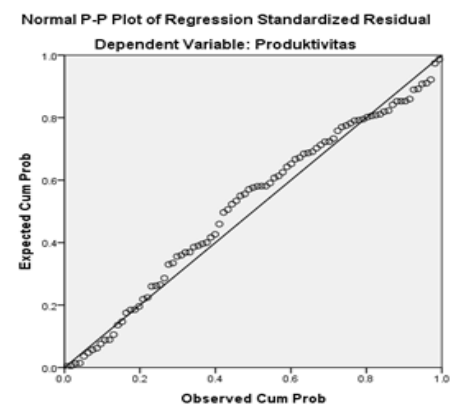

Sumber: Data diolah dengan IBM SPSS versi 23

\section{Gambar 4.1}

\section{Uji Normalitas Data P-P Plot}

Tabel 4.5. Hasil Uji Normalitas

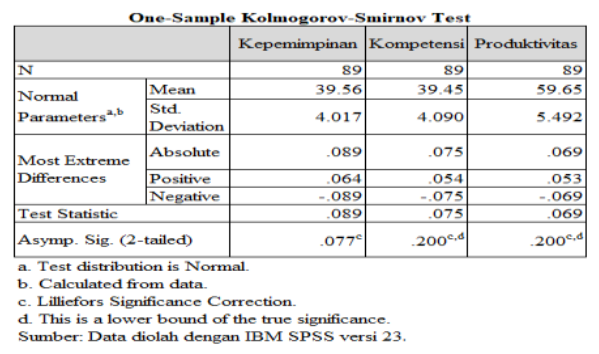

Bedasarkan gambar dan hasil olah data di atas menunjukkan sig kepemimpinan $0,077>0,05$, nilai sig kompetensi 0,200>0,05, dan nilai sig produktivitas pegawai 0,200 > 0,05 maka H0 tidak ditolak 


\section{Uji Homogenitas}

Tabel 4.6. Hasil Uji Homogenitas

Test of Homogeneity of Variances

\begin{tabular}{|l|r|r|r|r|}
\hline & $\begin{array}{r}\text { Levene } \\
\text { Statistic }\end{array}$ & \multicolumn{1}{c|}{ df1 } & \multicolumn{1}{c|}{ df2 } & \multicolumn{1}{c|}{ Sig. } \\
\hline KEPEMIMPINAN & 1.256 & 14 & 70 & .257 \\
\hline KOMPETENSI & 1.410 & 15 & 71 & .167 \\
\hline
\end{tabular}

Sumber: Data diolah dengan IBM SPSS versi 23 .

Berdasarkan hasil analisa di atas ditunjukan bahwa nilai sig kepemimpinan $0,257>0,05$ dan nilai sig kompetensi $0,167>0,05$ maka H0 tidak ditolak, dengan kata lain, asumsi homogenitas variansi dapat dikatakan dipenuhi.

\section{Uji Heteroskedastisitas}

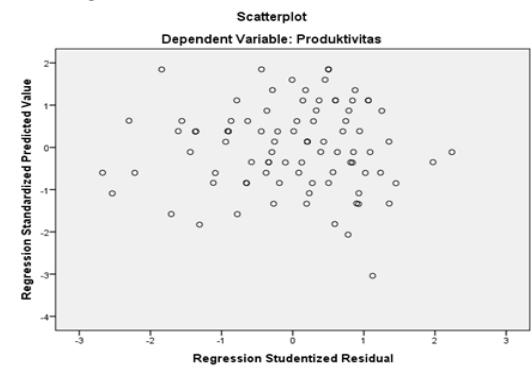

Gambar 4.2

Uji Heterokedastisitas

Dari grafik tersebut, dapat terlihat titik-titik yang menyebar secara acak, tidak membentuk suatu pola tertentu yang jelas, serta tersebar baik di atas maupun di bawah angka 0 (nol) pada sumbu Y, maka tidak terjadi heteroskedastisitas..

\section{Uji Multikolinearitas}

Tabel 4.7. Hasil Uji Multikolinieritas

\begin{tabular}{|c|c|c|c|c|}
\hline Model & \begin{tabular}{|c|} 
Collinearity \\
Statistics
\end{tabular} & & & \\
\hline & Tolerance & Kriteria & VIF & Kriteria \\
\hline Kepemimpinan & 0,149 & $>0,1$ & 6,703 & $<10$ \\
\hline Kompetensi & 0,149 & $>0,1$ & 6,703 & $<10$ \\
\hline
\end{tabular}

Berdasarkan hasil tersebut maka dalam model regresi tidak terjadi multikolinearitas atau korelasi yang sempurna antara variabelvariabel bebas, yaitu kepemimpinan dan kompetensi, karena nilai VIF lebih kecil dari 10 dan nilai tolerance lebih besar dari 0,1 .

\section{Uji Regresi Linier Berganda \\ Tabel 4.8. Hasil Uji Regresi} Linier Berganda

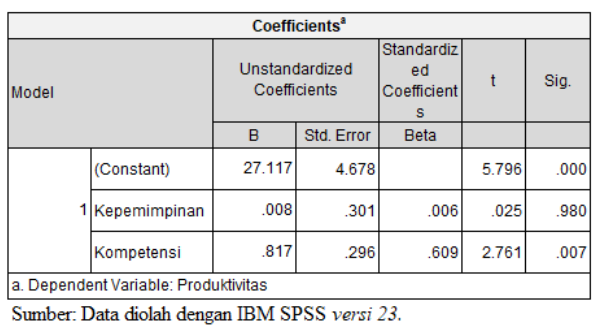

Berdasarkan hasil perhitungan tersebut maka dapat diperoleh persamaan regresi linier berganda sebagai berikut:

$\mathrm{Y}=27,117+0,008 \mathrm{X} 1+0,817 \mathrm{X} 2$

Dimana $\mathrm{X} 1=$ Kepemimpinan

$\mathrm{X} 2=$ Kompetensi

$\mathrm{Y}=$ Produktivitas Pegawai

a. Nilai konstanta sebesar 27,117 artinya apabila variabel kepemimpinan (X1) dan kompetensi (X2) dalam keadaan konstan, maka produktivitas pegawai (Y) adalah sebesar 27,117 .

b. Nilai regresi $0,008 \times 1$ artinya apabila variabel kepemimpinan (X1) meningkat 1 satuan dan variabel kompetensi (X2) tetap, maka produktivitas pegawai (Y) akan meningkat sebesar 0,008 satuan.

c. Nilai regresi 0,817X2 artinya apabila variabel kompetensi (X2) meningkat 1 satuan, dan variabel kepemimpinan (X1) tetap, maka 
produktivitas pegawai (Y) akan meningkat sebesar 0,817 satuan.

\section{Koefisien Determinasi Tabel 4.9. Hasil Koefisien Determinasi}

\begin{tabular}{|c|c|c|c|c|}
\hline \multicolumn{5}{|c|}{ Model Summary } \\
\hline Model & $\mathrm{R}$ & R Square & $\begin{array}{c}\text { Adjusted R } \\
\text { Square }\end{array}$ & $\begin{array}{l}\text { Std. Error of } \\
\text { the Estimate }\end{array}$ \\
\hline 1 & $.567^{\mathrm{a}}$ & .321 & .314 & 4.550 \\
\hline
\end{tabular}

Berdasarkan tabel di atas, dapat diketahui bahwa besarnya nilai koefisien determinasi ditunjukkan oleh nilai $\mathrm{R}$ Square yaitu sebesar 0,321 yang artinya bahwa kepemimpinan (X1) memberikan kontribusi terhadap variabel produktivitas pegawai (Y) sebesar $32,1 \%$, sedangkan sisanya sebesar $67,9 \%$ di pengaruhi oleh variabel lain yang tidak diteliti dalam penelitian ini.

\begin{tabular}{|c|c|c|c|c|}
\hline \multicolumn{5}{|c|}{ Model Summary } \\
\hline Model & $\mathrm{R}$ & R Square & $\begin{array}{l}\text { Adjusted } \\
\text { R Square }\end{array}$ & $\begin{array}{l}\text { Std. Error of } \\
\text { the Estimate }\end{array}$ \\
\hline 1 & $.614^{\mathrm{a}}$ & .377 & .369 & 4.361 \\
\hline \multicolumn{5}{|c|}{ a. Predictors: (Constant), Kompetensi } \\
\hline \multicolumn{5}{|c|}{ b. Dependent Variable: Produktivitas Pegawai } \\
\hline \multicolumn{5}{|c|}{ Sumber: Hasil Olahan Data SPSS 23} \\
\hline
\end{tabular}

Berdasarkan tabel di atas, nilai koefisien determinasi ditunjukkan oleh nilai $\mathrm{R}$ Square yaitu sebesar 0,377 yang artinya bahwa kompetensi (X2) memberikan kontribusi terhadap variabel produktivitas pegawai $(\mathrm{Y})$ sebesar 37,7\%, sedangkan sisanya sebesar $62,3 \%$ di pengaruhi oleh variabel lain yang tidak diteliti dalam penelitian ini.

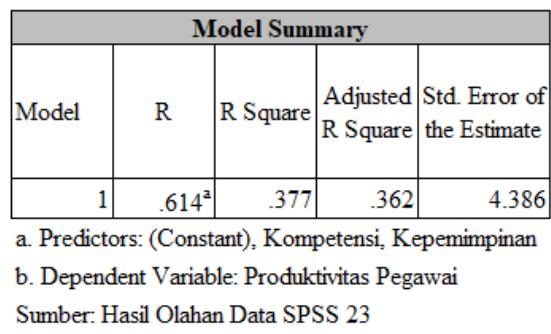

Berdasarkan tabel di atas, nilai koefisien determinasi ditunjukkan oleh nilai $\mathrm{R}$ Square yaitu sebesar 0,377 yang artinya bahwa dapat diketahui bahwa kepemimpinan (X1) dan kompetensi (X2) memberikan kontribusi terhadap variabel produktivitas pegawai (Y) sebesar $37,7 \%$, sedangkan sisanya sebesar $62,3 \%$ di pengaruhi oleh variabel lain yang tidak diteliti dalam penelitian ini.

\section{Uji Hipotesis Penelitian}

\section{Uji Parsial t-test}

\begin{tabular}{|c|c|c|c|c|}
\hline Model & t hitung & $\mathrm{t}$ tabel & Sig. & Keterangan \\
\hline Kepemimpinan & 6,418 & 1,987 & 0 & Signifikan \\
\hline
\end{tabular}

Nilai t hitung kepemimpinan (X1) sebesar 6,418> t tabel 1,987 (terlampir) dengan signifikan 0,000 $<$ 0,05 maka H0 ditolak dan Ha diterima menandakan bahwa kepemimpinan (X1) mempunyai pengaruh yang positif dan signifikan terhadap produktivitas pegawai (Y) pada PPSU Kelurahan Lebak Bulus. Lebih jelasnya gambar penolakan dan penerimaan hipotesis nol ditunjukkan di bawah ini:

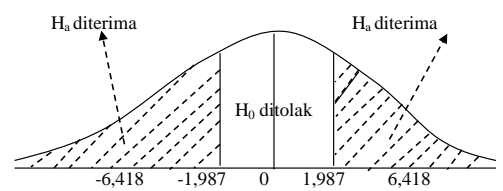

Berdasarkan Gambar 4.8 di atas lebih jelas terlihat bahwa nilai thitung jatuh di daerah penerimaan Ha yang 
berarti terdapat pengaruh yang positif dan signifikan secara parsial kepemimpinan terhadap produktivitas pegawai pada PPSU Kelurahan Lebak Bulus.

\begin{tabular}{|c|c|c|c|c|}
\hline Model & t hitung & $\mathrm{t}$ tabel & Sig. & Keterangan \\
\hline Kompetensi & 7,249 & 1,987 & 0 & Signifikan \\
\hline
\end{tabular}

Nilai t hitung kompetensi (X2) sebesar $7,249>\mathrm{t}$ tabel 1,987 (terlampir) dengan signifikan 0,000 $<0,05$ maka H0 ditolak dan Ha diterima menandakan bahwa kompetensi (X2) mempunyai pengaruh yang positif dan signifikan terhadap produktivitas pegawai (Y) pada PPSU Kelurahan Lebak Bulus. Lebih jelasnya gambar penolakan dan penerimaan hipotesis nol ditunjukkan di bawah ini:

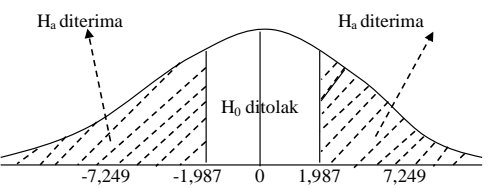

Gambar 4.3

Kriteria Penolakan dan Penerimaan Hipotesis X2

Berdasarkan Gambar 4.9 diatas lebih jelas terlihat bahwa nilai thitung jatuh di daerah penerimaan Ha yang berarti terdapat pengaruh yang positif dan signifikan secara parsial kompetensi terhadap produktivitas pegawai pada PPSU Kelurahan Lebak Bulus.

\section{Uji Simultan F-test}

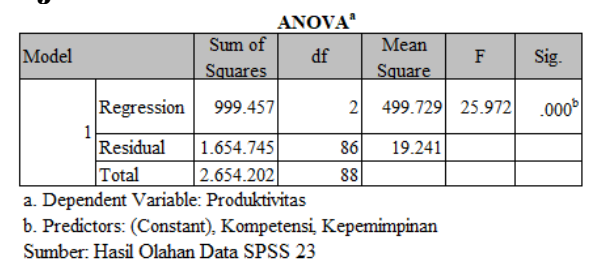

Berdasarkan tabel 4.28 menunjukkan hasil perhitungan diperoleh nilai $\mathrm{F}$ hitung sebesar 25,972 dengan tingkat signifikansi sebesar $0,000<0,05$. Sementara nilai $\mathrm{F}$ tabel sebesar 3,10 (dari perhitungan $\mathrm{dk} 1=2=0,05$ dan $\mathrm{dk}=89-2-1=86$ diperoleh $\mathrm{F}$ tabel 3,10). Ini berarti bahwa nilai Fhitung 25,972 > Ftabel 3,10 dengan siginifikan $0,000<0,05$ dengan demikian Ho ditolak dan $\mathrm{Ha}$ diterima, artinya bahwa kepemimpinan (X1) dan kompetensi (X2) berpengaruh secara simultan atau bersama-sama dan signifikan terhadap produktivitas pegawai pada PPSU Kelurahan Lebak Bulus. Lebih jelasnya gambar penolakan dan penerimaan hipotesis nol ditunjukkan di bawah ini:

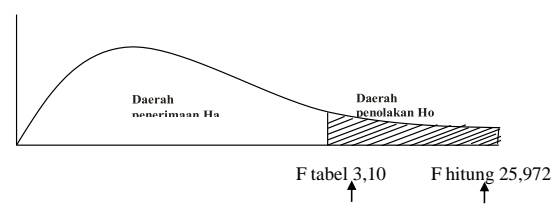

Gambar 4.4

\section{Kriteria Penolakan Hipotesis} Simultan

Hasil pengujian hipotesis simultan terlihat jelas bahwa nilai $\mathrm{F}$ hitung jatuh di daerah penolakan $\mathrm{H} 0$ yang berarti terdapat pengaruh yang positif dan signifikan secara simultan kepemimpinan dan kompetensi terhadap produktivitas pegawai pada PPSU Kelurahan Lebak Bulus.

\section{Pembahasan}

Setelah seluruh data yang diperoleh dalam penelitian diuraikan, maka pada tahap selanjutnya akan dilakukan pembahasan data yang telah diuraikan tadi. Interpretasi data secara keseluruhan untuk masingmasing variabel dapat dilakukan setelah terlebih dahulu 
diklasifikasikan berdasarkan nilainilai yang diperoleh dari responden.

Berdasarkan klasifikasi yang telah ditentukan, maka keseluruhan data yang diperoleh dari responden untuk masing-masing variabel penelitian dapat dijabarkan sebagai berikut :

\section{Pengaruh Kepemimpinan} terhadap Produktivitas $\left(\mathrm{X}_{1}-\right.$ Y)

Dari hasil analisis regresi yang telah dilaksanakan dapat diketahui nilai $\mathrm{t}$ hitung, langkah-langkah pengujian sebagai berikut:

a. Menentukan Hipotesis.

$\mathrm{H}_{0}=$ Tidak ada pengaruh positif dan signifikan antara kepemimipinan terhadap produktivitas pegawai. $\mathrm{H}_{\mathrm{a}} 1$ = Ada pengaruh positif dan signifikan antara kepemimpinan dengan kinerja karyawan .

b. Menentukan tingkat signifikansi.

Tingkat signifikansi menggunakan $\alpha=5 \%$ (signifikansi $5 \%$ atau 0,05 adalah ukuran standar yang sering digunakan dalam penelitian).

c. Menentukan t hitung.

Berdasarkan tabel 1,987 diperoleh $\mathrm{t}$ hitung sebesar 6,418 d. Menentukan $\mathrm{t}$ tabel.

Tabel distribusi t dicari pada $\alpha$ $=5 \%$ dengan derajat kebebasan

(df) $\mathrm{n}-2=87$. Hasil diperoleh untuk t tabel sebesar 1,987

e. Kriterian Pengujian.

Ho diterima jika $\mathrm{t}$ tabel $<\mathrm{t}$ hitung

Ho ditolak jika $\mathrm{t}$ hitung $>\mathrm{t}$ tabel f. Membandingkan $t_{\text {hitung dengan }}$

$\mathrm{t}$ tabel Nilai $\mathrm{t}$ hitung $>\mathrm{t}$ tabel $(6,418>1,987) \quad$ maka $\mathrm{H}_{\mathrm{O}}$

ditolak.

g. Kesimpulan.

Nilai $\mathrm{t}$ hitung $>\mathrm{t}$ tabel $=$ 6,418> 1,987 maka $\mathrm{H}_{\mathrm{O}}$ ditolak, artinya bahwa ada pengaruh yang kuat, positif dan signifikan antara kepemimpinan dengan produktivitas pegawai.

Nilai R (korelasi) adalah 0,567 dan nilai $R$ Square (determinasi) adalah 0,321, menunjukkan bahwa variabel $\mathrm{Y}$ (produktivitas pegawai) dipengaruhi oleh variabel $\mathrm{X}_{1}$ (kepemimpinan) sebesar $32,1 \%$ dan sisanya sebesar $67,9 \%$ dipengaruhi oleh faktorfaktor lain yang tidak diteliti. Jadi dalam kasus ini dapat disimpulkan bahwa kepemimpinan ber- pengaruh terhadap produktivitas pegawai, sehingga hipotesis awal yang menyatakan bahwa ada pengaruh yang signifikan antara kepemimpinan terhadap produktivitas pegawai dapat diterima.

Hasil ini sejalan dengan teori Hasibuan (2017:170) yang mengatakan bahwa kepemimpinan adalah cara seseorang mempengaruhi perilaku bawahannya, agar mau bekerja sama dan bekerja secara produktif untuk mencapai tujuan organisasi.

\section{Pengaruh Kompetensi terhadap} Produktivitas Pegawain $\left(\mathrm{X}_{2}-\right.$ Y)

Dari hasil analisis regresi yang telah dilaksanakan dapat diketahui 
nilai t hitung, langkah-langkah pengujian sebagai berikut:

a. Menentukan Hipotesis.

$\mathrm{H} 0$ = Tidak ada pengaruh

secara signifikan antara

kompetensi dengan kinerja

karyawan.

$\mathrm{H}_{\mathrm{a}} 1$ = Ada pengaruh positif

dan signifikan

antarakompetensi dengan

kinerja karyawan

b. Menentukan tingkat

signifikansi.

Tingkat signifikansi

menggunakan $\alpha=5 \%$

(signifikansi $5 \%$ atau 0,05

adalah ukuran standar yang

sering digunakan dalam

penelitian).

c. Menentukan t hitung.

Berdasarkan tabel .....

diperoleh $t$ hitung sebesar 7,249

d. Menentukan $t$ tabel.

Tabel distribusi t dicari pada $\alpha$ $=5 \%$ dengan derajat

kebebasan

(df) $\mathrm{n}-2=87$. Hasil diperoleh untuk $\mathrm{t}$ tabel sebesar 1,987.

e. Kriteria Pengujian

Ho diterima jika $\mathrm{t}$ tabel $<\mathrm{t}$

hitung Ho ditolak jika $t$ hitung

$>\mathrm{t}$ tabel

g. Membandingkan $t$ hitung dengan

$\mathrm{t}$ tabel Nilai t hitung $>\mathrm{t}$ tabel $(7,249>\mathrm{t}$ tabel 1,987$)$ maka $\mathrm{H}_{\mathrm{O}}$ ditolak.

h. Kesimpulan.

Nilai $\mathrm{t}$ hitung $>\mathrm{t}$ tabel $=7,249$

$>\mathrm{t}$ tabel 1,987 maka $\mathrm{H}_{\mathrm{O}}$

ditolak, artinya bahwa ada pengaruh yang kuat, positif dan signifikan antara kompetensi dengan kinerja karyawan.

Nilai R (korelasi) adalah 0,614 dan nilai $\mathrm{R}$ Square (determinasi) adalah 0,377, menunjukkan bahwa variabel $\mathrm{Y}$ (produktivitas pegawai) dipengaruhi oleh variabel $\mathrm{X}_{2}$ (kompetensi) sebesar 37,7\% dan sisanya sebesar $62,3 \%$ dipengaruhi oleh faktor-faktor lain yang tidak diteliti.

Jadi dalam kasus ini dapat disimpulkan bahwa kompetensi kerja berpengaruh terhadap produktivitas pegawai pada PPSU, sehingga hipotesis awal yang menyatakan bahwa ada pengaruh yang signifikan antara kompetensi kerja terhadap produktivitas pegawai dapat diterima.

Hasil ini sejalan dengan teori Spencer and Spencer dalam Sutrisno (2016:203), kompetensi sebagai karakteristik yang mendasari seseorang dan berkaitan dengan efektivitas produktivitas individu dalam pekerjaannya.

Jika kompetensi, sikap, dan tindakan karyawan terhadap pekerjaannya tinggi, maka diprediksikan bahwa perilakunya akan bekerja keras untuk mencapai tujuan organisasi, Wirawan ( 2012:10).

\section{Pengaruh Kepemimpinan dan}

Kompetensi terhadap

Produktivitas Pegawai (X1, X2 - Y)

Hasil penelitian melalui analisis regresi linier berganda menunjukkan bahwa kepemimpinan dan kompetensi sangat berpengaruh terhadap produktivitas pegawai. Hal ini dapat dilihat dari persamaan hasil regresi berikut : $\mathbf{Y}=$ 27,117+0,008X1+0,817X2

Di mana : 
a. Berdasarkan hasil regresi linier berganda nilai regresi yang diperoleh $\mathrm{Y}=$ $27,117+0,008 \mathrm{X} 1+0,817 \mathrm{X} 2$

Nilai konstanta sebesar 27,117 artinya apabila variabel kepemimpinan (X1) dan kompetensi (X2) dalam keadaan konstan, maka produktivitas pegawai (Y) adalah sebesar 27,117 .

b. Nilai korelasi sebesar 0,614 menunjukan bahwa secara bersama-sama hubungan kepemimpinan (X1) dan kompetensi (X2) terhadap produktivitas pegawai (Y) pada PPSU Kelurahan Lebak Bulus memiliki tingkat hubungan yang kuat.

c. Nilai koefisien determinasi sebesar 0,377 yang artinya bahwa dapat diketahui bahwa kepemimpinan (X1) dan kompetensi (X2) memberikan kontribusi terhadap variabel produktivitas pegawai (Y) sebesar $37,7 \%$, sedangkan sisanya sebesar $62,3 \%$ di pengaruhi oleh variabel lain yang tidak diteliti dalam penelitian ini.

d. Nilai Fhitung 25,972 > F tabel 3,10 dengan siginifikan 0,000 $<0,05$ dengan demikian Ho ditolak dan Ha diterima, artinya bahwa kepemimpinan (X1) dan kompetensi (X2) berpengaruh secara simultan atau bersama-sama dan signifikan terhadap produktivitas pegawai pada PPSU Kelurahan Lebak Bulus.

Berdasarkan hasil uji $\mathrm{F}$ secara bersama-sama penelitian diperoleh besarnya pengaruh kepemimpinam dan kompetensi terhadap produktivitas pegawai sebesar 0,690 dengan determinasi $\left(\mathrm{R}^{2}\right) 47,6 \%$ dan sisanya $52,4 \%$ dipengaruhi oleh variabel lain yang belum diperhitungkan dalam penelitian ini.

Hasil ini sejalan dengan teori yang telah dibahas di dalam Bab II dimana kemampuan seseorang dipengaruhi pemahamannya atas jenis pekerjaan dan keterampilan melakukannya, oleh karenanya seseorang harus dapat meningkatkan kerja maupun dan kete-rampilannya. Selain itu kontribusi kepe- mimpinan, terhadap produktivitas pegawai tidaklah dapat diabaikan.

Menurut Sinungan (2009:1) pada dasarnya produktivitas mencakup sikap mental patriotik yang memandang hari depan secara optimis dengan berakar kepada keyakinan diri bahwa kehidupan hari ini adalah lebih baik dari hari kemarin dan hari esok adalah lebih baik dari hari ini.

Menurut Sutrisno (2016:107) terdapat 3 aspek utama yang perlu ditinjau dalam menjamin produktivitas yang tinggi, yaitu ; aspek kemampuan manajemen tenaga kerja, aspek efisiensi tenaga kerja, dan aspek kondisi lingkungan pekerjaan.

\section{KESIMPULAN DAN SARAN Kesimpulan}

Setelah peneliti melakukan analisa mengenai pengaruh kepemimpin dan kompetensi terhadap produktivitas pegawai Penanganan, Prasarana dan Sarana Umum Lebak Bulus Jakarta Selatan, maka berdasarkan pembahasan hasil penelitian tersebut dapat disimpulkan sebagai berikut: 
1. Secara parsial variabel kepemimpinan $\left(\mathrm{X}_{1}\right)$ berpengaruh secara kuat, positif dan sangat signifikan terhadap variabel produktivitas pegawai (Y) dengan nilai $\mathrm{t}$ hitung $(6,418)>\mathrm{t}$ tabel $(1,987)$ dan signifikansi lebih kecil dari $5 \%(0,000<0,05)$. Diperoleh hasil uji persamaan regresi : $\mathbf{Y}=$ $\mathbf{2 8 , 9 9 2 + 0 , 7 7 5 X}$

Nilai R (korelasi) adalah 0,567 dan nilai $\mathrm{R}$ Square (determinasi) adalah 0,321, menunjukkan bahwa variabel Y (kinerja karyawan) dipengaruhi oleh variabel $\mathrm{X}_{1}$ (disiplin) sebesar $32,1 \%$ dan sisanya sebesar $67,9 \%$ dipengaruhi oleh faktor-faktor lain yang tidak diteliti.

2. Terdapat pengaruh yang positif dan signifikan kompetensi terhadap produktivitas pegawai PPSU pada Kelurahan Lebak Bulus, Jakarta Selatan. Hal ini dapat dibuktikan dari nilai, koefisien determinasi sebesar $37,7 \%$, dan nilai t hitung 7,249> t tabel 1,987 dengan signifikan $0,000<0,05$.

Secara parsial variabel kompetensi $\left(\mathrm{X}_{2}\right)$ berpengaruh secara kuat, positif dan signifikan terhadap variabel produktivitas pegawai (Y) dengan nilai $\mathrm{t}$ hitung $(7,249)>\mathrm{t}$ tabel $(1,987)$ dan signifikansi lebih kecil dari $5 \%(0,000<0,05)$. Diperoleh hasil uji persamaan regresi : $\mathbf{Y}=$ 27,146+0,824X.

Nilai R (korelasi) adalah 0,614 dan nilai $\mathrm{R}$ Square (determinasi) adalah 0,377, menunjukkan bahwa variabel $\mathrm{Y}$ (produktivitas pegawai) dipengaruhi oleh variabel $\mathrm{X}_{3}$ (kompetensi) sebesar $37,7 \%$ dan sisanya sebesar $62,3 \%$ dipengaruhi oleh faktor-faktor lain yang tidak diteliti.

3. Terdapat Secara bersama-sama terdapat pengaruh yang positif dan signifikan kepemimpinan dan kompetensi terhadap produktivitas pegawai PPSU pada Kelurahan Lebak Bulus, Jakarta Selatan. Hal ini dapat dibuktikan dari persamaan regresi linier berganda yaitu $\mathrm{Y}=$ $27,117+0,008 \mathrm{X} 1+0,817 \mathrm{X} 2$, nilai koefisien korelasi sebesar 0,614 , koefisien determinasi sebesar 37,7\% dan nilai Fhitung 25,972 > Ftabel 3,10 dengan signifikan $0,000<0,05$

4. Dalam pengujian secara simultan dengan menggunakan uji $F$ menunjukkan adanya pengaruh yang sangat signifikan variabel kepemimpinan $\left(\mathrm{X}_{1}\right)$ dan variabel kompetensi $\left(\mathrm{X}_{2}\right)$, secara bersamasama terhadap variabel produktivitas pegawai (Y). Hal dibuktikan dengan nilai $\mathrm{F}$ hitung $(25,972)>F$ tabel $(3,100)$ dan signifikansi lebih kecil dari 5\% $(0,000<0,05)$. Diperoleh hasil uji persamaan regresi berganda:

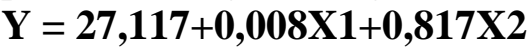

Berdasarkan hasil uji $\mathrm{F}$ secara bersama-sama diperoleh pula besarnya pengaruh kepemimpinan, dan kompetensi terhadap kinerja karyawan. Dengan nilai R (korelasi) adalah 0,614 dan nilai $\mathrm{R}$ Square (determinasi) adalah 0,377, menunjukkan bahwa variabel $\mathrm{Y}$ (produktivitas pegawai) dipengaruhi oleh variabel $\mathrm{X}_{1}$ (kepemimpinan) dan variabel $\mathrm{X}_{2}$ (kompetensi) secara bersama-sama, sebesar $37,7 \%$ dan sisanya sebesar $62,3 \%$ dipengaruhi oleh faktor-faktor lain yang tidak diteliti. 


\section{Saran}

Berdasarkan data kuesioner yang telah diolah dan kesimpulan di atas, maka penulis mengajukan beberapa saran yang diharapkan dapat bermanfaat bagi PPSU Kelurahan Lebak Bulus yaitu sebagai berikut:

1. Dari hasil kuesioner variabel kepemimpinan $\left(\mathrm{X}_{1}\right) \quad$ yang mempunyai nilai skor terendah yaitu indikator kewibawaan $(62,9 \%)$ dalam variabel kepemimpinan, dengan demikian maka disarankan agar pimpinan perlu meningkatkan komunikasi secara langsung tidak hanya dalam pekerjaan saja namun juga memperhatikan langsung dalam menyelesaikan masalah baik masalah pribadi maupun masalah kelompok. Sehingga tercapainya rasa kagum terhadap pemimpin dan menjadi nyaman dalam bekerja. Pemimpin yang memiliki kewibawaan yang baik akan membuat pegawai menghargai dan mematuhi arahan dari pimpinan tanpa ada paksaan, karena apabila pegawai merasa menjadikan pemimpinnya menjadi teladan dalam bekerja dan tidak ada jarak antara pemimpin dan pegawai maka pegawai akan terpacu untuk meningkatkan produktivitasnya dalam melaksanakan pekerjaannya.

2. Berdasarkan jawaban responden variabel kompetensi $\left(\mathrm{X}_{2}\right)$ yang mempunyai nilai skor terendah adalah pernyataan karyawan mengenai kemampuan (65,2\%). Skill (kemampuan) merupakan indikator terendah dikarenakan sebagian pegawai merasa bahwa mereka masih mengalami kesulitan dalam mengerjakan suatu tugas tertentu dengan cepat, dengan demikian, maka penulis menyarankan agar para pegawai lebih menggali lagi kemampuan yang dimiliki dalam bekerja serta belajar secara terus menerus dan menggunakan pengalaman yang dimiliki dalam bekerja, karena dengan belajar secara terus menerus serta dengan melihat dari pengalaman akan memberikan dampak kepada pegawai yang akan menjadikan pegawai dalam bekerja menjadi lebih efektif dan bagaimapun kondisi yang terjadi pada saat bekerja dengan mengerahkan seluruh kemampuan yang dimiliki sehingga peningkatan produktivitas dalam mencapai tujuan dapat tercapai dengan baik. Manajemen juga dapat memberikan pelatihan kepada pegawai tentang bagaimana cara penanganan prasana dan sarana umum yang ada kelurahan secara cepat, tepat dan cermat dengan menggunakan teknologi yang canggih.

3. Pengaruh kepemimpinan dan kompetensi terhadap produktivitas pegawai mem- punyai pengaruh yang positif dan signifikan terhadap variabel produktivitas pegawai, dengan memiliki tingkat hu- bungan yang kuat, maka diharapkan pimpinan dapat mempertahankan dan menerapkan kepemimpinan yang lebih baik sehingga pegawai mempunyai produktivitas yang baik secara konsisten bahkan meningkatkan hasil pekerjaannya. 
DAFTAR PUSTAKA

Algifari, "Analisis Regresi Teori, Kasus dan Solusi Edisi Kedua". BPFE. Yogyakarta, 2010.

Fuad, Noor., Ahmad, Gofur. "Integrated HRD", PT. Gramedia, Jakarta, 2009.

Ghozali, Imam. “Aplikasi Analisis Multivariate Dengan Ibm Spss 23".Edisi Ke-8. BP Universitas Diponegoro, Semarang, 2016.

Harari, Oren. "The Leadership of Collin Powel , Seluruh Paradigma Baru Kepemimpinan", Gramedia, Jakarta, 2005

Hasibuan, Malayu S.P. "Manajemen Sumber Daya Manusia". (Edisi Revisi.Cetakan Kedelapan Belas) Bumi Aksara, Jakarta, 2017.

Hasibuan, Malayu S.P. "Manajemen Dasar, Pemngertian, dan Masalah". (Edisi Revisi.) Bumi Aksara, Jakarta, 2009.

Lensufiie, Tikno. "Leadership untuk Profesional dan Mahasiswa". Erlangga. Jakarta, 2010.

Mahanggoro, Tri Patra, "Melejitkan Produktivitas Kerja dengan Sinergitas Kecerdasan (ESPQ) Tinjauan Studi Ilmu Kesehatan", CV Budi Utama, Sleman, 2018.

Mangkunegara, Anwar Prabu. "Manajemen Sumber Daya Manusia Perusahaan”. Cetakan
Kesepuluh. Remaja

Rosdakarya, Bandung, 2011.

Nawawi, Hadari. "Perencanaan SDM untuk organisasi profit yang kompetitif", Gajah Mada University Press, Yogyakarta, 2015.

Noor, Juliansyah. "Metodologi Penelitian". PT. Pernada Media, Jakarta, 2011.

Sagala, Syaiful. "Pendekatan dan Model Kepemimpinan", PT. Gramedia, Jakarta, 2018.

Sedarmayanti. "Manajemen Sumber Daya Manusia Reformasi Birokrasi dan Manajemen Pegawai Negeri Sipil”.Cetakan Keenam, Refika Aditama, Bandung, 2013.

Sinungan, "Produktivitas Apa dan Bagaimana." Cetakan Kedelapan. Bumi Aksara, Jakarta, 2009.

Stephen P. Robbins and Timothy A. Judge. "Perilaku Organisasi (Organizational Behavior"). Edisi Keenam Belas, Salemba Empat, Jakarta, 2014.

Sugiyono. "Metodologi Penelitian Kuantitatif, Kualitatif, dan R\&D”. Cetakan Kedua Tiga. Alfabeta, Bandung, 2016.

Sugiyono. "Metode Penelitian Kombinasi (Mix Methods)". Alfabeta, Bandung, 2015.

Sugiyono. "Statistika Untuk Penelitian". Cetakan Kedua 
Delapan. Alfabeta, Bandung, 2017.

Supardi. "Aplikasi Statistika dalam Penelitian Konsep Statistika yang Lebih Komprehensif'. Change Publication, Jakarta, 2013.

Sutrisno, Edy. "Manajemen Sumber Daya Manusia". Cetakan Kedelapan.: Kencana, Jakarta, 2016.

Terry, George. "Prinsip-Prinsip Manajemen". Bumi Aksara, Jakarta, 2013.

Terry, George. "Dasar-Dasar Manajemen". Bumi Aksara, Jakarta, 2014.

Wijono, Sutarto, . "Kepemimpinan dalam Perspektif Organisasi”, Prenadamedia Group, Jakarta, 2018.

Wirawan, Evaluasi Kinerja Sumber Daya Manusia Teori”, Aplikasi, dan Penelitian, Salemba Empat, Jakarta. 2012

Daftar Jurnal

Aulia, Figur. "Pengaruh Kepemimpinan Terhadap Produktivitas Kerja Pegawai Di Kantor Dinas Kesejahteraan Sosial Kota Samarinda". Samarinda. E-journal Ilmu Pemerintahan 5 (2);593-604. ISSN 2477-2631. 2017

Margareta. "Kepemimpinan Dan Motivasi Kerja Pengaruhnya Terhadap Produktivitas Kerja Pegawai Di Kantor Camat Sario Kota Manado". Manado. Jurnal
EMBA Vol 1 No 4. ISSN : 2303-1174. 2013

Nuryanto. Saryuti Enggok, Murakham. Abdurrahman, Akhmad, "Pengaruh Kompetensi Terhadap Produktivitas Kerja Pegawai Kantor Unit Penyelenggara Pelabuhan Kelas III Satui”. Banjarmasin. Jurnal Ilmu Administrasi dan Manajemen Vol 1 No 1. e-ISSN : 25809695. 2017.

Syopwani. "Pengaruh Kepemimpinan dan Kompetensi Terhadap Kinerja Pegawai Kantor Kecamatan Pancoran Kota Administrasi Jakarta Selatan". Jurnal Renasissance Vol 2 No 1. e-ISSN : 2527-564X

Wasti. "Pengaruh Kompetensi dan Semangat Kerja Terhadap Produktivitas Kerja di Kantor Kecamatan Long Hubung Kabupaten Mahakam Ulu". Kalimantan Timur. Jurnal Pemerintahan Integratif Vol 5 No 2. ISSN : 2337-8670. 2017. 